\title{
The alcohol dehydrogenase isoenzyme (ADH IV) as a candidate tumour marker of esophageal cancer
}

\author{
Wojciech Jelski ${ }^{\boxplus}$, Magdalena Laniewska-Dunaj', Jacek Niklinski², Miroslaw Kozłowski², \\ Jerzy Laudanski² and Maciej Szmitkowski ${ }^{1}$
}

'Department of Biochemical Diagnostics; ${ }^{2}$ Department of Thoracic Surgery, Medical University, Białystok, Poland

\begin{abstract}
Objective: Alcohol dehydrogenase (ADH) and aldehyde dehydrogenase (ALDH) are present in esophageal cancer cells. Moreover the total activity of ADH as well as the activity of class IV ADH isoenzyme is significantly higher in cancer tissue than in healthy mucosa. The activity of these enzymes in cancer cells is reflected in the sera and could thus be helpful for diagnostics of esophageal cancer. The aim of this study was to investigate a potential significance of ADH isoenzymes and ALDH as tumour markers of esophageal cancer. We defined diagnostic sensitivity, specificity, predictive value for positive and negative results, and receiver-operating characteristics (ROC) curve for tested enzymes. Methods: Serum samples were taken for routine biochemical investigation from 180 patients with esophageal cancer before treatment. Total ADH activity was measured by a photometric method with p-nitrosodimethylaniline as a substrate and ALDH activity by a fluorometric method with 6-methoxy-2-naphtaldehyde as a substrate. For the measurement of the activity of class I and II isoenzymes we employed the fluorometric methods, with class-specific fluorogenic substrates. The activity of class III alcohol dehydrogenase was measured by a photometric method with formaldehyde and class IV with $\mathrm{m}$ nitrobenzaldehyde as a substrate. Results: There was a significant increase in the activity of class IV of ADH isoenzyme $(7.65 \mathrm{mU} / \mathrm{l}$ vs $5.88 \mathrm{mU} / \mathrm{l})$ and total $\mathrm{ADH}$ activity $(1198 \mathrm{mU} / \mathrm{l}$ vs $848 \mathrm{mU} / \mathrm{l})$ in the sera of esophageal cancer patients compared to the control. The diagnostic sensitivity for ADH IV was $72 \%$, the specificity $76 \%$, the positive and negative predictive values were $80 \%$ and $72 \%$ respectively. The area under the ROC curve for $A D H$ IV was 0.65 . Conclusion: The results suggest a potential significance of ADH IV as a marker of esophageal cancer.
\end{abstract}

Key words: alcohol dehydrogenase isoenzymes, esophageal cancer

Received: 19 June, 2013; revised: 04 September, 2013; accepted: 11 September, 2013; available on-line: 19 September, 2013

\section{INTRODUCTION}

Esophageal cancer (EC), an aggressive upper gastrointestinal tract malignancy, is the sixth most common cause of cancer-related death. An estimated 482300 new esophageal carcinoma cases and 406,800 deaths occurred in 2008 worldwide (Jemal et al., 2011). It is a disease characterized by relatively late diagnosis, rapid clinical progression, and very poor patients' survival. Therefore it is very important to find markers that would detect malignant cells transformation as early as possible. The changes in enzyme activity in the cancer cells during the course of different neoplastic diseases are reflected by an increase in the corresponding enzyme activity in the serum. Numerous studies have shown that alcohol dehydrogenase $(\mathrm{ADH})$ and aldehyde dehydrogenase $(\mathrm{ALDH})$ are present in cells of human esophageal tissues and perform many important physiological functions (Vaglenova et al., 2003; Yin et al., 1993). The esophageal mucosa contains class I, III and IV ADH isoenzymes and several classes of ALDH isoenzymes (Estonius et al., 1996; Goedde \& Agarwal, 1987). In our previous study we have found that alcohol dehydrogenase and its isoenzymes are present in the esophageal cancer cells. In addition we also showed that the total activities of $\mathrm{ADH}$ and class IV $\mathrm{ADH}$ isoenzyme were significantly higher in cancer tissues than in healthy mucosa (Jelski et al., 2009a). The activities of these enzymes are reflected in the serum. The total ADH activity has been elevated in the sera of patients with esophageal cancer. The increase in total ADH activity was positively correlated with class IV ADH and seems to be caused by the release of this isoenzyme from the cancer tissue (Jelski et al., 2009b).

In the current investigation we defined the diagnostic criteria such as diagnostic sensitivity, diagnostic specificity, positive predictive value, negative predictive value, and receiver-operating characteristics (ROC) curve of the tested enzymes.

\section{MATERIALS AND METHODS}

Patients. The protocol was approved by the Human Care Committee of the Medical University in Bialystok, Poland (Approval Nr R-I-002/176/2007). All patients gave informed consent for the examination.

Serum samples were taken for routine biochemical investigations from 180 patients $(117$ males and 63 females, aged 35-80 years) with esophageal cancer. Among the cancer patients, 82 subjects ( 50 men and 32 women) suffered from esophageal adenocarcinoma and 98 persons (67 men, 31 women) from squamous cell cancer of the esophagus (Table 1). The clinical diagnosis of

e-mail: wjelski@umb.edu.pl

Abbreviations: $\mathrm{ADH}$, alcohol dehydrogenase; AJCC, American Joint Committee on Cancer; ALDH, aldehyde dehydrogenase; AUC, area under curve; CEA, carcinoembryonic antigen; CRC, colorectal cancer; CT, computer tomography; EC, esophageal cancer; GC, gastric cancer; IL-6, interleukin 6; M-CSF, macrophage-colony stimulating factor; MMP-9, metalloproteinase 9; NAD, nicotinamide adenine dinucleotyde; NADH, nicotinamide adenine dinucleotide, reduced form; NDMA, nitrosodimethylaniline; ROC, receiver-operating characteristics; SCC-Ag, squamous cell cancer antigen. 
Table 1. Characteristics of esophageal cancer patients and control group

\begin{tabular}{|c|c|c|c|c|}
\hline & & \multicolumn{2}{|c|}{ No of patients } & \multirow{2}{*}{$\frac{\text { No of patients }}{80}$} \\
\hline & Esophageal cancer patients & 180 & Control group & \\
\hline & \multicolumn{2}{|c|}{ Esophageal adenocarcinoma $(\mathrm{n}=82)$} & \multicolumn{2}{|c|}{ Esophageal squamous cell $(\mathrm{n}=98$ ) } \\
\hline \multirow{2}{*}{ Gender } & Males & $50(61 \%)$ & $67(68 \%)$ & $54(67 \%)$ \\
\hline & Females & $32(39 \%)$ & $31(32 \%)$ & $26(33 \%)$ \\
\hline \multirow{3}{*}{ Age } & $<65$ years & $46(56 \%)$ & $56(57 \%)$ & $59(74 \%)$ \\
\hline & $\geq 65$ years & $36(44 \%)$ & $42(43 \%)$ & $21(26 \%)$ \\
\hline & Range & $35-80$ & $39-71$ & $35-72$ \\
\hline \multirow{3}{*}{ Tumour stage } & $\| A$ & 32 & 34 & \\
\hline & II B & 11 & 12 & \\
\hline & III & 39 & 52 & \\
\hline \multirow{2}{*}{ Tumour size } & $<4 \mathrm{~cm}$ & 38 & 46 & \\
\hline & $\geq 4 \mathrm{~cm}$ & 44 & 52 & \\
\hline \multirow{4}{*}{$\begin{array}{l}\text { Depth } \\
\text { of tumour invasion }\end{array}$} & $\mathrm{T} 1$ & 0 & 7 & \\
\hline & $\mathrm{T} 2$ & 30 & 34 & \\
\hline & $\mathrm{T} 3$ & 37 & 48 & \\
\hline & $\mathrm{T} 4$ & 15 & 9 & \\
\hline \multirow{2}{*}{ Lymph node metastases } & No & 39 & 40 & \\
\hline & N1 & 43 & 58 & \\
\hline \multirow{2}{*}{ Distant metastases } & MO & 82 & 98 & \\
\hline & M1 & 0 & 0 & \\
\hline Amount of alcohol intake & $\begin{array}{l}\text { Moderate } \\
\text { - males: } \\
\text { - females: }\end{array}$ & $\begin{array}{l}82 \\
50 \\
32\end{array}$ & $\begin{array}{l}98 \\
67 \\
31\end{array}$ & $\begin{array}{l}80 \\
54 \\
26\end{array}$ \\
\hline \multirow{2}{*}{ Resectability } & Resectable & 46 & 59 & \\
\hline & Nonresectable & 36 & 39 & \\
\hline
\end{tabular}

esophageal cancer was established by barium and chest radiography; endoscopy of the tracheobronchial tree, larynx and esophagus; CT examination of the thorax and abdomen. The diagnosis was each time confirmed by microscopic examination of the material obtained during biopsy. Using the TNM data obtained from tumour and lymph node status, the patients were categorized according to the American Joint Committee on Cancer (AJCC) classification. All cancer patients were in stage II or III.

None of the patients had received chemo- or radiotherapy before serum collection. All of the patients drank alcohol occasionally and self-reported an intake of $<25 \mathrm{~g}$ of ethanol per week. The data were collected by using a standardized questionnaire during a face-to-face interview.

Serum samples were also obtained from 80 healthy adults aged 35-72 years (men -54 , women - 26) as a control group. None of them consumed any drug or alcohol.

Biochemical assays. Determination of total $\mathrm{ADH}$ activity. Total ADH activity was estimated by a photometric method with p-nitrosodimethylaniline (NDMA) as a substrate (Jelski et al., 2008a \& Skursky et al., 1979). The reduction of NDMA was monitored at $440 \mathrm{~nm}$ on a Shimadzu UV/VIS 1202 spectrophotometer (Shimadzu Europa GmbH, Duisburg, Germany).

Determination of total ALDH activity. Aldehyde dehydrogenase activity was measured using a fluorogenic method based on the oxidation of 6-methoxy-2-naphtaldehyde to the fluorescent 6-methoxy-2 naphtoate (Jelski et al., 2008b). The fluorescence was read at an excitation wavelength of 310 and an emission wavelength of 360 $\mathrm{nm}$ on a Shimadzu RF-5301 spectrofluorophotometer (Shimadzu Europa GmbH, Duisburg, Germany).

Determination of class I and II ADH isoenzyme activity. Class I and II ADH isoenzyme activities were measured using fluorogenic substrates (4-methoxy1-naphthaldehyde for class I and 6-methoxy-2-naphthaldehyde for class II) in reduction reaction according to Wierzchowski et al. (1989). The measurements were performed on a Shimadzu RF-5301 spectrofluorophotometer at excitation wavelenght of $316 \mathrm{~nm}$ for both substrates and emission of $370 \mathrm{~nm}$ for class I and $360 \mathrm{~nm}$ for class II isoenzymes.

Determination of class III $\mathrm{ADH}$ isoenzyme activity. The activity of class III ADH isoenzyme was estimated by a photometric method with formaldehyde as a substrate (Koivusalo et al., 1989). The reduction of NAD was monitored at $340 \mathrm{~nm}$ and $25^{\circ} \mathrm{C}$ on a Shimadzu UV/ VIS 1202 spectrophotometer.

Determination of class IV ADH isoenzyme activity. Class IV ADH isoenzyme activity was measured using a photometric method with m-nitrobenzaldehyde as a substrate (Dohmen et al., 1996). The oxidation of $\mathrm{NADH}$ was monitored at $340 \mathrm{~nm}$ and $25^{\circ} \mathrm{C}$ on a Shimadzu UV/VIS 1202 spectrophotometer.

Diagnostic values calculation. The diagnostic criteria, such as diagnostic sensitivity, specificity, predictive and negative value and the ROC curve were determined using GraphRoc Program for Windows (Univer- 


$$
\begin{aligned}
& \text { Sensitivity }=\frac{\text { number of true-positive results }}{100 \%} \\
& \text { number of true-positive results }+ \text { number of false-negative results } \\
& \text { Specificity }=\frac{\text { number of true-negative results }}{100 \%} \\
& \text { number of true-negative results }+ \text { number of false-positive results } \\
& \text { Positive predictive value }=\frac{\text { number of true-positive results }}{\text { number of true-positive }+ \text { number of false-positive }} \times 100 \% \\
& \text { results results }
\end{aligned}
$$

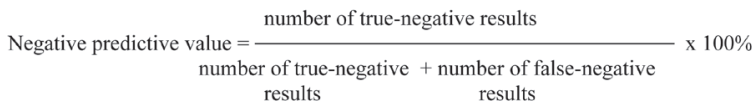

\section{Scheme 1}

sity of Turku, Turku, Finland) (Kairisto et al., 1993) (see Scheme 1).

Statistical analysis. A preliminary statistical analysis (Chi-square test) revealed that the distribution of $\mathrm{ADH}$ and ALDH activities did not follow a normal distribution. Consequently, the Wilcoxon's test was used for statistical analysis. Data were presented as median, range and mean values. Statistically significant differences were defined as comparisons resulting in $p<0.05$.

\section{RESULTS}

The activities of alcohol dehydrogenase, aldehyde dehydrogenase and the isoenzymes of alcohol dehydrogenase in the sera of patients with esophageal cancer are presented in Table 2. The comparison of $\mathrm{ADH}$ isoenzyme activities showed that a high difference was exhibited by class IV ADH. The median activity of this class of isoenzyme in the total cancer group increased by about $23 \%(7.65 \mathrm{mU} / \mathrm{l})$ in comparison with the control level $(5.88 \mathrm{mU} / \mathrm{l})$. This increase was statistically significant $(p<0.001)$. The activity of the other tested classes of ADH isoenzymes showed a tendency to increase in the sera of patients with cancer, but the differences were not statistically significant. The total alcohol

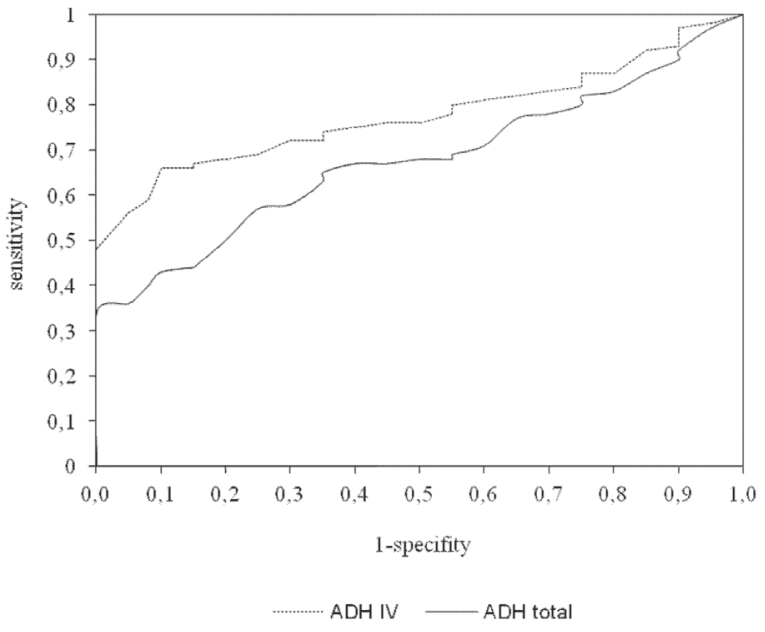

$\mathrm{ADH} I V$, Area $=0.8223, \mathrm{SE}=0.0514$

$\mathrm{ADH}$ total, Area $=0.6926, \mathrm{SE}=0.0603$

Figure 1. Areas under ROC curves for ADH IV and total ADH activity.

dehydrogenase activity was significantly higher (29\%) in patients with esophageal cancer than in the healthy subjects $(p<0.001)$. The median total activity of $\mathrm{ADH}$ was $1198 \mathrm{mU} / 1$ in the patient group and $848 \mathrm{mU} / 1$ in control group. The analysis of ALDH activity did not show any significant difference between the tested groups of esophageal cancer patients and healthy persons.

The analysis of $\mathrm{ADH}, \mathrm{ALDH}$ and $\mathrm{ADH}$ isoenzyme activities in the serum did not indicate significant differences between patients with adenocarcinoma and squamous cell cancer.

Table 3 shows the diagnostic criteria for $\mathrm{ADH}$ total and ADH IV. The sensitivity $(72 \%)$ and specificity $(76 \%)$ of $\mathrm{ADH}$ IV were higher than the values for $\mathrm{ADH}$

\begin{tabular}{|c|c|c|c|c|c|c|}
\hline $\begin{array}{l}\text { Tested } \\
\text { Group }\end{array}$ & $\begin{array}{l}\text { ADH I } \\
\text { Median } \\
\text { Range }\end{array}$ & $\begin{array}{l}\text { ADH II } \\
\text { Median } \\
\text { Range }\end{array}$ & $\begin{array}{l}\text { ADH III } \\
\text { Median } \\
\text { Range }\end{array}$ & $\begin{array}{l}\text { ADH IV } \\
\text { Median } \\
\text { Range }\end{array}$ & $\begin{array}{l}\text { ADH Total } \\
\text { Median } \\
\text { Range }\end{array}$ & $\begin{array}{l}\text { ALDH } \\
\text { Median } \\
\text { Range }\end{array}$ \\
\hline $\begin{array}{l}\text { Patients with esophageal } \\
\text { cancer (total group) } \\
(n=180)\end{array}$ & $\begin{array}{c}1.55 \\
0.71-3.14\end{array}$ & $\begin{array}{c}15.89 \\
7.03-23.89\end{array}$ & $\begin{array}{c}12.56 \\
5.46-19.42\end{array}$ & $\begin{array}{c}7.65 \\
4.36-15.97\end{array}$ & $\begin{array}{c}1198 \\
605-3068\end{array}$ & $\begin{array}{c}3.04 \\
1.12-5.86\end{array}$ \\
\hline $\begin{array}{l}\text { Patients with esophageal } \\
\text { adenocarcinoma } \\
(\mathrm{n}=82)\end{array}$ & $\begin{array}{c}1.68 \\
0.80-3.14\end{array}$ & $\begin{array}{c}16.47 \\
7.46-23.89\end{array}$ & $\begin{array}{c}12.83 \\
6.01-19.42\end{array}$ & $\begin{array}{c}7.98 \\
4.72-15.97\end{array}$ & $\begin{array}{c}1221 \\
732-3068\end{array}$ & $\begin{array}{c}3.17 \\
1.42-5.86\end{array}$ \\
\hline $\begin{array}{l}\text { Patients with esophageal } \\
\text { squamous cell cancer } \\
(n=98)\end{array}$ & $\begin{array}{c}1.49 \\
0.71-2.85\end{array}$ & $\begin{array}{c}15.22 \\
7.03-21.76\end{array}$ & $\begin{array}{c}12.15 \\
5.46-18.97\end{array}$ & $\begin{array}{c}7.48 \\
4.36-15.54\end{array}$ & $\begin{array}{c}1170 \\
605-2804\end{array}$ & $\begin{array}{c}2.85 \\
1.12-5.32\end{array}$ \\
\hline \multirow[t]{2}{*}{$\begin{array}{l}\text { Control group } \\
(n=80)\end{array}$} & $\begin{array}{c}1.46 \\
0.57-2.77\end{array}$ & $\begin{array}{c}15.67 \\
7.09-21.94\end{array}$ & $\begin{array}{c}12.11 \\
5.05-18.82\end{array}$ & $\begin{array}{c}5.88 \\
2.45-11.86\end{array}$ & $\begin{array}{c}848 \\
514-2397\end{array}$ & $\begin{array}{c}2.81 \\
1.02-5.35\end{array}$ \\
\hline & $\begin{array}{l}\mathrm{p}^{\mathrm{a}}=0.543 \\
\mathrm{p}^{\mathrm{b}}=0.364 \\
\mathrm{p}^{\mathrm{c}}=0.512 \\
\mathrm{p}^{\mathrm{d}}=0.467\end{array}$ & $\begin{array}{l}\mathrm{p}^{\mathrm{a}}=0.426 \\
\mathrm{p}^{\mathrm{b}}=0.503 \\
\mathrm{p}^{\mathrm{c}}=0.589 \\
\mathrm{p}^{\mathrm{d}}=0.485\end{array}$ & $\begin{array}{l}\mathrm{p}^{\mathrm{a}}=0.425 \\
\mathrm{p}^{\mathrm{b}}=0.363 \\
\mathrm{p}^{\mathrm{c}}=0.584 \\
\mathrm{p}^{\mathrm{d}}=0.505\end{array}$ & $\begin{array}{l}\mathrm{p}^{\mathrm{a}}<0.001 \\
\mathrm{p}^{\mathrm{b}}<0.001 \\
\mathrm{p}^{\mathrm{c}}<0.001 \\
\mathrm{p}^{\mathrm{d}}=0.635\end{array}$ & $\begin{array}{l}\mathrm{p}^{\mathrm{a}}<0.001 \\
\mathrm{p}^{\mathrm{b}}<0.001 \\
\mathrm{p}^{\mathrm{c}}<0.001 \\
\mathrm{p}^{\mathrm{d}}=0.608\end{array}$ & $\begin{array}{l}\mathrm{p}^{\mathrm{a}}=0.265 \\
\mathrm{p}^{\mathrm{b}}=0.372 \\
\mathrm{p}^{\mathrm{c}}=0.438 \\
\mathrm{p}^{\mathrm{d}}=0.316\end{array}$ \\
\hline
\end{tabular}
total. Both the positive predictive value and the negative predictive value were also the highest for ADH IV.

The relationship between diagnostic sensitivity and specificity was illustrated by a ROC curve (Fig. 1). It

Table 2. ADH and ALDH activity in the sera of patients with esophageal cancer

Data are expressed as $\mathrm{mU} / \mathrm{l} ; \mathrm{p}^{\mathrm{a}}$, patients with esophageal cancer versus control group. $\mathrm{p}^{\mathrm{b}}$, patients with esophageal adenocarcinoma versus control group. $\mathrm{p}^{c}$, patients with esophageal squamous cell cancer versus control group. $\mathrm{p}^{\mathrm{d}}$, patients with esophageal adenocarcinoma versus patients with esophageal squamous cell cancer. 
Table 3. Diagnostic criteria for ADH total and ADH IV in esophageal cancer

\begin{tabular}{|c|c|c|c|c|c|}
\hline & $\begin{array}{l}\text { Cut-off } \\
\mathrm{mU} / \mathrm{l}\end{array}$ & $\begin{array}{c}\text { Diagnostic sensitivity } \\
(\%)\end{array}$ & $\begin{array}{c}\text { Diagnostic specificity } \\
(\%)\end{array}$ & $\begin{array}{l}\text { Positive predictive value } \\
(\%)\end{array}$ & $\begin{array}{c}\text { Negative predictive value } \\
(\%)\end{array}$ \\
\hline ADH total & 2200 & 56 & 65 & 68 & 67 \\
\hline ADH IV & 8.50 & 72 & 76 & 80 & 72 \\
\hline
\end{tabular}

The cut-off points were obtained from a study of a healthy population (95th percentile); $A D H ~ I V, A r e a=0.6563, S E=0.0514 ; A D H$ total, Area $=0.6026$, $\mathrm{SE}=0.0603$

shows that the ADH IV area under the ROC curve (0.66) was higher than the ROC area of $\mathrm{ADH}$ total $(0.60)$.

\section{DISCUSSION}

Patients with esophageal carcinoma usually experience rapid disease progression and face a poor prognosis, which is due to extensive local cancer invasion, lymph nodes involvement, and distant metastases at the time of the diagnosis (Vallbohmer \& Lenz, 2006). Various tumour markers have been used in the diagnosis of patients with esophageal cancer. The most commonly used tumour markers for EC are squamous cell cancer antigen (SCC-Ag) and carcinoembryonic antigen (CEA), but their diagnostic sensitivity and specificity remain unsatisfactory (Guillem \& Triboulet, 2005). Therefore, other biomarkers are necessary in the diagnosis of esophageal cancer. For a long time attempts have been made to find markers to detect malignant cell transformation as early as possible (Linblom \& Liljegren, 2000).

In our previous study we have shown that the total activity of $\mathrm{ADH}$ is significantly higher in cancer cells of the esophagus than in healthy mucosa and the activity of ALDH does not differ between both tissues. In addition the activity of ALDH in the cancer cells seems to be disproportionally low in relation to $\mathrm{ADH}$ activity. This would suggest that there is much greater ethanoloxidizing activity and considerably less acetaldehyde-oxidizing activity. Moreover we found that only the activity of class IV $\mathrm{ADH}$ (the main isoenzyme of $\mathrm{ADH}$ in the esophageal mucosa) is significantly higher in cancer than in healthy tissue (Jelski et al., 2009a). The increase in enzyme activity in the cancer cells is reflected by increased activity in the serum. In our previous study we found that the total alcohol dehydrogenase activity was changed in the serum of patients with esophageal cancer. The increase intotal ADH activity was positively correlated with ADH IV implicating that the latter isoenzyme was mainly responsible for the increase of total serum alcohol dehydrogenase activity in the course of esophageal cancer (Jelski et al., 2009b). The present study is a continuation of our previous research. Higher levels of $\mathrm{ADH}$ in patients with more advanced tumour might result from enzyme release by cancer cells and could be helpful for diagnosing EC. The ideal marker should possess very high specificity, and sensitivity. It should have high predictive values and should correlate with the tumour stage. In our present paper, diagnostic sensitivity was highest for ADH IV $(72 \%)$ and ADH total $(56 \%)$. The percentage increase in ADH IV activity in EC patients was four-fold higher than that of CEA $(17 \%)$ and higher than that of SCC-Ag (64\%) (Mroczko et al. 2008). Some previous analyses have shown elevated concentration of metalloproteinase 9 (MMP-9), circulating cytokines such as macrophage-colony stimulating factor (M-CSF) and interleukin 6 (IL-6) in patients with esophageal cancer (Mroczko et al., 2008; Lukaszewicz-Zajac et al., 2010; Lukaszewicz-Zajac et al., 2011). Only the sensitivity of IL-6 $(86 \%)$ is markedly higher than the sensitivity of ADH IV, while the sensitivities of M-CSF (71\%) and MMP-9 (70\%) are very similar when compared to that of ADH IV.

In this study we found that the ADH IV area under the ROC curve (0.65) was smaller than the area under curve (AUC) for tumour markers (SCC-Ag, 0.81; CEA, 0.67) (Mroczko et al., 2008). Moreover AUC of ADH IV and ADH total was lower than those of other biomarkers of esophageal cancer, such as MMP-9 (0.73), M-CSF (0.72) and IL-6 (0.92) (Mroczko et al., 2008; Lukaszewicz-Zajac et al., 2010; Lukaszewicz-Zajac et al., 2011). The area under the ROC curve indicates the clinical usefulness of tested substances

The results in the present paper are in agreement with other studies performed on the stomach (Jelski et al., 2010a). Our previous study demonstrated the potential importance of ADH IV as a marker of gastric cancer (GC). The diagnostic criteria for ADH IV are slightly higher in gastric cancer than in esophageal cancer. The sensitivity and specificity of class IV ADH in GC patients was $73 \%$ and $79 \%$, respectively.

The total activity of alcohol dehydrogenase is higher in the cancer cells of different organs than in healthy tissue. Previously we have shown that the serum activities of $\mathrm{ADH}$ I and $\mathrm{ADH}$ total were higher in colorectal cancer (CRC) patients than in healthy controls (Jelski et al., 2010b). In our investigations we have found also that the activity of class III ADH in the serum changed in the course of pancreatic cancer (Jelski et al., 2011). ADH I and ADH III could be helpful for diagnostics of CRC and pancreatic cancer, respectively.

In conclusion, according to our knowledge, the present study is the first showing all the diagnostic criteria for alcohol dehydrogenase and aldehyde dehydrogenase in esophageal cancer patients. These results suggest a potential significance of $\mathrm{ADH}$ (especially $\mathrm{ADH}$ IV) as a marker of EC.

\section{Conflict of interest}

The authors declare that they have no conflict of interest related to the publication of this manuscript.

\section{REFERENCES}

Estonius M, Svensson S, Hoog J-O (1996) Alcohol dehydrogenase in human tissue: localisation of transcripts coding for five classes of the enzyme. FEBS Lett 397: 338-42.

Dohmen K, Baraona E, Ishibashi H (1996) Ethnic differences in gastric s-alcohol dehydrogenase activity and ethanol first pass metabolism. Alcohol Clin Exp Res 20: 1569-1576.

Goedde HW, Agarwal DP (1987) Polymorphism of aldehyde dehydrogenase and alcohol sensitivity. Enzyme 37: 29-44.

Guillem P, Triboulet J (2005) Elevated serum levels of C-reactive protein are indicative of a poor prognosis in patients with esophageal cancer. Dis Esophagus 18: 146-150.

Jelski W, Chrostek L, Zalewski B, Szmitkowski M (2008a) Alcohol dehydrogenase $(\mathrm{ADH})$ isoenzymes and aldehyde dehydrogenase 
(ALDH) activity in the sera of patients with gastric cancer. Dig Dis Sci 53: 2101-2105.

Jelski W, Kozlowski M, Laudanski J, Niklinski J, Szmitkowski M (2009a) The activity of class I, II, III, and IV alcohol dehydrogenase $(\mathrm{ADH})$ isoenzymes and aldehyde dehydrogenase $(\mathrm{ALDH})$ in esophageal cancer. Dig Dis Si 54: 725-730.

Jelski W, Kozlowski M, Laudanski J, Niklinski J, Szmitkowski M (2009b) Alcohol dehydrogenase isoenzymes and aldehyde dehydrogenase activity in the sera of patients with esophageal cancer. Clin Exp Med 9: 131-137.

Jelski W, Kutylowska E, Laniewska-Dunaj M, Szmitkowski M (2011) Alcohol dehydrogenase $(\mathrm{ADH})$ and aldehyde dehydrpgenase $(\mathrm{ALDH})$ as candidates for tumor markers in patients with pancreatic cancer. J Gastroenterol Liver Dis 20: 255-259.

Jelski W, Mroczko B, Szmitkowski M (2010b) The diagnostic value of alcohol dehydrogenase (ADH) isoenzymes and aldehyde dehydrogenase (ALDH) measurement in the sera of colorectal cancer patients. Dig Dis Sci 55: 2953-2957.

Jelski W, Orywal K, Laniewska M, Szmitkowski M (2010a) The diagnostic value of alcohol dehydrogenase $(\mathrm{ADH})$ isoenzymes and aldehyde dehydrogenase (ALDH) measurement in the sera of gastric cancer patients. Clin Exp Med 10: 215-219.

Jelski W, Zalewski B, Szmitkowski M (2008b) Alcohol dehydrogenase $(\mathrm{ADH})$ isoenzymes and aldehyde dehydrogenase (ALDH) activity in the sera of patients with pancreatic cancer. Dig Dis Sci 53: 22762280 .

Jemal A, Bray F, Center MM, Ferlay J, Ward E, Forman D (2011) Global cancer statistics. CA Cancer I Clin 61: 69-90.

Kairisto V, Virtanen A, Uusipaikka E, Voipio-Pulkki LM, Näntö V, Peltola O, Irjala K (1993) Method for determining reference changes from patients' serial data: example of cardiac enzymes. Clin Chem 39: 2298-2304.

Koivusalo M, Baumann M, Uotila L (1989) Evidence for the identity of glutathione- dependent formaldehyde dehydrogenase and class III alcohol dehydrogenase. FEBS Lett 257: 105-109.
Lindblom A, Liljegren A (2000) Tumour markers in malinancies. BMJ 320: $424-427$.

Lukaszewicz-Zajac M, Mroczko B, Kozlowski M, Niklinski J, Laudanski J, Szmitkowski M (2010) Clinical significance of serum macrophage-colony stimulating factor (M-CSF) in esophageal cancer patients and its comparison with classical tumor markers. Clin Chem Lab Med 48: 1467-1473.

Lukaszewicz-Zajac M, Mroczko B, Kozlowski M, Niklinski J, Laudanski J, Szmitkowski M (2012) Higher importance of interleukine 6 (IL-6) than classical tumor markers (CEA and SCC-Ag) in the diagnosis of esophageal cancer patients. Dis Esophagus 25: 242-249.

Mroczko B, Kozlowski M, Groblewska M, Lukaszewicz M, Niklinski J, Jelski W, Laudanski J, Chyczewski L, Szmitkowski M (2008) The diagnostic value of measurement of matrix metalloproteinase 9 (MMP-9), squamos cell cancer antigen (SCC) and carcinoembryonic antigen (CEA) in the sera of esophageal cancer patients. Clin Chim Acta 389: 61-66.

Skursky L, Kovar J, Stachova M (1979) A sensitive assay for alcohol dehydrogenase activity in blood serum. Anal Biochem 89: 65-71.

Vaglenova J, Martinez SE, Porte S, Duester G, Farres J, Pares X (2003) Expression, localization and potential physiological significance of alcohol dehydrogenase in the gastrointestinal tract. Eur $J$ Biochem 270: 2652-2662.

Vallbohmer D, Lenz HJ, (2006) Predictive and prognostic molecular markers in outcome of esophageal cancer. Dis Esophagus 19: 425432.

Wierzchowski J, Dafeldecker WP, Holmquist B, Vallee BL (1989) Fluorimetric assay for isozymes of human alcohol dehydrogenase. Anal Biochem 178: 57-62.

Yin S-J, Chou F-J, Chao S-F, Tsai S-F, Liao C-S, Wang S-L, Wu C-W, Lee S-C (1993) Alcohol and aldehyde dehydrogenases in human esophagus: comparison with the stomach enzyme activities. Alcohol Clin Exp Res 17: 376-381. 